\title{
Enhancement of nitrate removal at the sediment-water interface by carbon addition plus vertical mixing
}

Xuechu Chen* a,b, Shengbing He ${ }^{\mathrm{a}}$, Yueping Zhang ${ }^{\mathrm{c}}$, Xiaobo Huang ${ }^{\mathrm{a}}$, Yingying Huang ${ }^{\mathrm{a}}$, Danyue Chen ${ }^{\mathrm{a}}$, Jianwu Tang ${ }^{\mathrm{b}}$, Xiaochen Huang ${ }^{\mathrm{c}}$

${ }^{a}$ School of Environmental Science and Engineering, Shanghai Jiao Tong University, Dong Chuan Road 800, Shanghai, 200240, P. R. China.

${ }^{b}$ Ecosystems Center, Marine Biological Laboratory, 7 MBL Street, Woods Hole, MA 02543, USA

${ }^{c}$ Shanghai East Sea Marine Engineering Survey \& Design Institute, Shanghai 200137, P.R. China

\section{Abstract}

Wetlands and ponds are frequently used to remove nitrate from effluents or runoffs. However, the efficiency of this approach is limited. Based on the assumption that introducing vertical mixing to water column plus carbon addition would benefit the diffusion across the sediment-water interface, we conducted simulation experiments to identify a method for enhancing nitrate removal. The results suggested that the sediment-water interface has a great potential for nitrate removal, and the potential can be activated after several days of acclimation. Adding additional carbon plus mixing significantly increases the nitrate removal capacity, and the removal of total nitrogen (TN) and nitrate-nitrogen $\left(\mathrm{NO}_{3}{ }^{-} \mathrm{N}\right)$ is well fitted to a first-order reaction model. Adding Hydrilla verticillata debris as a carbon source increased nitrate removal, whereas adding Eichhornia crassipe decreased it. Adding ethanol plus *Corresponding author Tel: +86-21-34203734 FAX: +86-21-54740825 E-mail address: cxcsnow@163.com 
mixing greatly improved the removal performance, with the removal rate of $\mathrm{NO}_{3}{ }^{-}-\mathrm{N}$ and $\mathrm{TN}$ reaching 15.0-16.5 $\mathrm{g} \mathrm{m}^{-2} \mathrm{~d}^{-1}$. The feasibility of this enhancement method was further confirmed with a wetland microcosm, and the $\mathrm{NO}_{3}^{-}-\mathrm{N}$ removal rate maintained at 10.0-12.0 $\mathrm{g} \mathrm{m}^{-2} \mathrm{~d}^{-1}$ at a hydraulic loading rate of $0.5 \mathrm{~m} \mathrm{~d}^{-1}$.

\section{Keyword}

Nitrate removal, Sediment-water interface, Carbon addition, Vertical mixing

\section{Introduction}

Surface runoffs in some valleys are under a high load of nitrate from sewage plants and agricultural non-point sources. These runoffs ultimately flow into lakes or estuaries and are likely to cause the occurrence of harmful algal blooms (Kroeger et al., 2006; Galloway et al., 2008; Suddick et al., 2013). In many countries, such as the United States and China, in order to remove nitrate from effluents or runoffs, wetlands, riparian buffer strips, and ponds have been restored or artificially constructed at the interface between cultivated land and receiving waters. However, the efficiency of these ecological approaches is limited, and a large amount of land is usually required to achieve satisfactory removal (Jorgensen et al., 1994; Reilly et al., 1999; Coveney et al., 2002). Therefore, developing measures to improve nitrate removal is of increasing interest.

Denitrification is a microbial-mediated process that uses nitrate as an electron acceptor and organic carbon as an electron donor to obtain energy for growth and maintenance. In this stepwise process, nitrite, nitric oxide and nitrous oxide are produced as intermediate products and nitrogen $\left(\mathrm{N}_{2}\right)$ as the gaseous end product. The availability of carbon and nitrate, oxygen concentration, $\mathrm{pH}$ and temperature are main parameters influencing denitrification. In wetlands, plant productivity, either from biomass or 
root release can be used as the internal carbon source to fuel denitrification. Previous studies suggested that supplying additional carbon is an alternative measure for improving nitrate removal in wetlands or ponds. It can be achieved by optimizing the physical habitat for maximum plant productivity or harvesting the plants but leaving the residuals in place (Lin et al., 2002; Bastviken et al., 2005; Wen et al., 2010). However, the improvement in nitrate removal by such internal carbon sources is limited and is usually below $1 \mathrm{~g} \mathrm{~m}^{-2} \mathrm{~d}^{-1}$. When an external carbon source such as acetate is added, the nitrate removal capacity would increase to its maximum, about $4 \mathrm{~g} \mathrm{~m}^{-2} \mathrm{~d}^{-1}$. (Ingersoll and Baker, 1998; Vidal et al., 2002; Pungrasmi et al., 2013).

Unlike the biological denitrification process, which involves controlling requisite anoxic conditions in a bioreactor, wetland denitrification occurs in anoxic zones of the sediment-water interface or in anoxic microsites of a biofilm attached to plant tissue or substrata (Pfenning and McMahon, 1997; Bruesewitz et al., 2011; Yu et al., 2012; Finlay et al., 2013). The sediment-water interface is a shallow, oxic-anoxic layer that separates a mixture of solid sediment and interstitial water from an overlying body of water (Lerman, 1978; Sweerts et al., 1991). Recent studies on natural wetlands and ponds have indicated that the nitrate and carbon across the water-sediment interface would be consumed more quickly than with an internal vertical diffusive supply, and as a result, limiting the nitrate removal (Reinhardt et al., 2006; Wilson et al., 2013). Accordingly, when supplying additional carbon to wetlands or ponds, the diffusive carbon and nitrate supply across sediment -water interface might become a limiting factor instead of carbon source itself. Therefore, we hypothesize that introducing vertical mixing to water column plus carbon addition would benefit the diffusion across sediment-water interface, and thus further enhance the nitrite removal capacity to an extremely high level.

To our knowledge, although previous studies investigated various kinds of carbon sources that can 
enhance nitrate removal in wetlands or ponds, rare studies focuses on regulating mass diffusing across sediment - water interface. This study focuses on nitrate removal at the sediment-water interface of wetlands or pond systems with the following objectives: to comprehensively investigate the nitrate removal potential at sediment-water interface; to determine the mechanism for the increase of nitrate removal by carbon addition plus vertical mixing; to identify a feasible method for engineering application.

\section{Materials and Methods}

\subsection{Batch test}

The experiment was conducted in growth chambers with the temperature maintained at $25-26{ }^{\circ} \mathrm{C}$. The reactor for the batch tests was a small glass cylinder with a diameter of $15 \mathrm{~cm}$ and a height of $25 \mathrm{~cm}$. The surface sediment samples $(0-10 \mathrm{~cm})$ were collected from a lake located at the Shanghai Jiao Tong University, Minhang campus, by using Ekman-type grab sampler $(15.2 \mathrm{~cm} \times 15.2 \mathrm{~cm})$. After removing the gravel and plant and animal residues, the sediment samples were mixed and transferred to the cylinders, maintaining a layer of $5 \mathrm{~cm}$. Then, $15 \mathrm{~cm}$ of lake water was injected into each cylinder, and stabilized for $24 \mathrm{~h}$ before the tests were initiated. There was a slight variation $(<5 \%)$ in the average concentration of total nitrogen $(\mathrm{TN})$, nitrite-nitrogen $\left(\mathrm{NO}_{2}{ }^{-}-\mathrm{N}\right)$, nitrate-nitrogen $\left(\mathrm{NO}_{3}{ }^{-} \mathrm{N}\right)$, and dissolved oxygen (DO) in the overlying water before and after stabilization, whereas the ammonia-nitrogen $\left(\mathrm{NH}_{4}^{+}-\mathrm{N}\right)$ increased from $0.71 \mathrm{mg} \mathrm{L}^{-1}$ to $1.14 \mathrm{mg} \mathrm{L}^{-1}$. This result suggests that the release of nitrogen from the sediment is limited. After stabilization, $\mathrm{NaNO}_{3}$ was added to each cylinder to obtain a high nitrate concentration for further investigating the removal capacity. As the amount of external $\mathrm{NO}_{3}{ }^{-}-\mathrm{N}$ was much higher than the $\mathrm{NH}_{4}{ }^{+}-\mathrm{N}$ released from sediment, we suggested that coupled denitrificaiton was not the main nitrate loss path during our experiments. 
The batch tests were designed to illustrate the nitrate removal under different sediment-water interface conditions and its potential. The tests were divided into two phases. In phase I, the experiment had 5 treatments, and each treatment had two duplicates. For treatment $1^{\#}$ and treatment $2^{\#}$, the sediment surface was covered with gravel and zeolite (particle size of 4-8 mm, approximately 1-2 cm deep), respectively. For treatment $3^{\#}$, methanol was added as an additional carbon source (methanol/ $\mathrm{NO}_{3}{ }^{-}-\mathrm{N}$ mass ratio of $4: 1$ ). For treatment $4^{\#}$, the overlying water was mixed with a peristaltic pump at a flow rate of $25 \mathrm{~mL} \mathrm{~min}{ }^{-1}$. Treatment $5^{\#}$ was the control. In phase II, the overlying water was adjusted with methanol and $\mathrm{NaNO}_{3}$ to maintain the methanol/ $\mathrm{NO}_{3}{ }^{-}-\mathrm{N}$ mass ratio at 4:1. During the experiment, when the TN and nitrate concentration decreased to a relatively low level, lake water with same methanol $/ \mathrm{NO}_{3}{ }^{-} \mathrm{N}$ mass ratio was again added to each cylinder. A total of four rounds of continuous removal experiments were performed. Sampling was performed every 1-2 d. Before sampling, the overlying water was mixed for approximately $5 \mathrm{~s}$ with a peristaltic pump. Then, $15 \mathrm{~mL}$ water was sampled from the upper, middle and lower layer of the overlying water. The sample was mixed for further analysis. To maintain a constant water volume, deionized water was added after each sampling. During the entire experimental process, the $\mathrm{pH}$ value was maintained between 7.0 and 7.5.

\subsection{Column experiment}

The experimental reactor was a Y-shape structure, comprising two polymethyl methacrylate columns (He et al., 2013). The main column had a 20-cm-inner diameter and was $120 \mathrm{~cm}$ in height, and the side cylinder portion had a $20 \mathrm{~cm}$-inner diameter and was $20 \mathrm{~cm}$ in height. Both ends of the columns were sealed with a plastic stopper. Two mechanical agitators, fixed on the stoppers, were used to stir the water. Prior to the experiment, sediment that was corrected and treated as described above was filled to the main column, maintaining a layer of $10 \mathrm{~cm}$. Then, lake water was injected into the experimental apparatus for 
a $100 \mathrm{~cm}$ deep, and stabilized for $24 \mathrm{~h}$. The equivalent height of overlying water was approximately 1.2 m when taking the side cylinder portion into account. During the experiments, $\mathrm{NaNO}_{3}$ was added to obtain a high nitrate concentration for evaluation. Ethanol, methanol, and Hydrilla verticillata and Eichhornia crassipes debris were added as carbon sources. To introduce the proper mixing conditions, the frequencies of the vertical and side agitator were maintained at 80 and $36 \mathrm{r} \mathrm{min}^{-1}$, respectively. These conditions permitted mixing of the overlying water without disturbing the sediment surface because the suspended matter rarely increased when the agitators operated. The $\mathrm{pH}$ value of the overlying water was maintained at 7.0-8.0. The water temperature was approximately $30 \pm 1{ }^{\circ} \mathrm{C}$. Each day, approximately 20 $\mathrm{mL}$ water was sampled from the upper, middle and lower layers of the overlying water and was mixed for further analysis. For the methanol addition treatment, when the nitrate concentration of the overlying water decreased to a low level, nitrate and organic carbon sources were added again.

\subsection{Wetland microcosm}

The wetland microcosm was comprised of polymethyl methacrylate and consisted of two main units and three water distribution cells (Fig. 1). The first unit was a floating plants pond, primarily designed for denitrification. The pond was $45 \mathrm{~cm} \times 60 \mathrm{~cm} \times 70 \mathrm{~cm}$ (inner width, length, and height) in size, with a water depth maintained at $60 \mathrm{~cm}$. The surface of the pond was covered by duckweed, and the bottom was filled with 10 centimeters of sediment. During the experiment, the overlying water was mixed with a pump with a flow rate of $120 \mathrm{~mL} \mathrm{~min}{ }^{-1}$. The second unit was a gravel bed filter, measuring $15 \mathrm{~cm} \times 60$ $\mathrm{cm} \times 50 \mathrm{~cm}$ (inner width, length, and height). It was filled with 1- to 2-cm-diameter gravel, and an aeration device was installed at the bottom to provide aerobic conditions and allow for chemical oxygen demand (COD) removal and nitrification through contact with the surface of the gravel. To optimize the water flow, three water distribution cells with perforated baffles were located between the treatment units. 
The source water was tap water augmented with $\mathrm{NaNO}_{3}$ to a concentration of $20-25 \mathrm{mg} \mathrm{NO}_{3}^{-}-\mathrm{N} \mathrm{L}^{-1}$. The water was pumped into the wetland and then flowed through the floating plant pond and gravel bed filter. The water temperature during the experiment was approximately $26 \pm 1^{\circ} \mathrm{C}$. The main hydraulic loading rate of the wetland was maintained at $0.5 \mathrm{~m} \mathrm{~d}^{-1}$ with a hydraulic retention time of approximately 32 hours.

\subsection{Analysis methods}

The samples were analyzed for $\mathrm{TN}$ and $\mathrm{COD}_{\mathrm{cr}}$, and the filtered samples were analyzed for $\mathrm{NH}_{4}{ }^{+}-\mathrm{N}$, $\mathrm{NO}_{3}{ }^{-}-\mathrm{N}, \mathrm{NO}_{2}^{-}-\mathrm{N}$. All analytical measurements were recorded according to Standard Methods (APHA, 1995). According to results of the batch tests (Fig. 2), the nitrate removal was estimated by the following formula: $\mathrm{C}=\mathrm{C}_{0} \mathrm{e}^{-k \mathrm{~T}}$, where $\mathrm{C}$ is the $\mathrm{TN}$ or $\mathrm{NO}_{3}{ }^{-}-\mathrm{N}$ concentration in the control and treatments, $k$ is the specific removal rate, and $\mathrm{T}$ is the incubation time. The error bars was analyzed by using SPSS13.0 statistical soft.

\section{Results and discussion}

\subsection{Nitrate removal under different sediment-water interface conditions and its potential}

Fig. 2 shows nitrate removal under different sediment-water interface conditions. The reduction of TN and $\mathrm{NO}_{3}{ }^{-}-\mathrm{N}$ was well fitted by an exponential curve. The coefficients of determination $\left(\mathrm{R}^{2}\right)$ ranged from 0.87 to 0.99 , suggesting the reaction followed the first-order reaction model. The amount of $\mathrm{NO}_{3}{ }^{-}-\mathrm{N}$ removal accounted for the majority amount of $\mathrm{TN}$ removal (always above 80\%), suggesting that denitrification was the primary pathway of nitrogen loss during the experiment. The incubations with methanol as the carbon source showed the highest specific $\mathrm{NO}_{3}{ }^{-}-\mathrm{N}$ removal rate of $1.27 \mathrm{~d}^{-1}$, and within 3 days, the $\mathrm{NO}_{3}^{-}-\mathrm{N}$ concentration decreased from $9.8 \mathrm{mg} \mathrm{L}^{-1}$ to almost $0 \mathrm{mg} \mathrm{L}^{-1}$. Of the other four treatments without additional carbon, the treatment with mixing had the highest $\mathrm{TN}$ and $\mathrm{NO}_{3}{ }^{-}-\mathrm{N}^{-}$removal 
rate $\left(0.15 \mathrm{~d}^{-1}\right.$ and $0.17 \mathrm{~d}^{-1}$ respectively), indicating that mixing promotes nitrate removal. To test our presumption that mass diffusion across sediment-water interface influences nitrate removal, the sediment surface of two incubations was covered with bed media, gravel and zeolite. As anticipated, the covering inhibited the nitrate removal as the specific removal rates of these two treatments were much lower than the incubations with the natural water-sediment interface.

Because denitrification is a microbial-mediated process, $\mathrm{NO}_{3}{ }^{-}-\mathrm{N}$ removal at the sediment-water interface may increase after acclimation of denitrifying bacteria. Therefore, we conducted four rounds of continuous removal experiments with a methanol/ $\mathrm{NO}_{3}{ }^{-} \mathrm{N}$ mass ratio of $4: 1$ to investigate the nitrate removal potential (Fig.3). An increase in $\mathrm{NO}_{3}{ }^{-}-\mathrm{N}$ removal was maintained during the first three rounds of the experiments (0-4 d, 5-7 d and 8-10 d), and for the $4^{\text {th }}$ round, the average $\mathrm{NO}_{3}{ }^{-} \mathrm{N}$ removal rate increased to $2.31 \mathrm{~g} \mathrm{~m}^{-2} \mathrm{~d}^{-1}$. Comparatively, the incubation without additional carbon showed a low efficiency of nitrate removal, with an average removal rate of $0.21 \mathrm{~g} \mathrm{~m}^{-2} \mathrm{~d}^{-1}$. After 13 days of incubation, we assume that the denitrifying bacteria were acclimated, and the nitrate removal potential in water-sediment interface was at its limit. Thereafter, the overlying water was adjusted to a higher $\mathrm{NO}_{3}{ }^{-}-\mathrm{N}$ concentration of $20 \mathrm{mg} \mathrm{L}^{-1}$, with a methanol/ $\mathrm{NO}_{3}{ }^{-}-\mathrm{N}$ mass ratio of $4: 1$. The frequency of sampling was shortened to hours to reflect the dynamics of the nitrate removal. As shown in Fig. 4, the result confirmed that the removal of $\mathrm{TN}$ and $\mathrm{NO}_{3}{ }^{-}-\mathrm{N}$ was well fitted to a first-order reaction model.

\subsection{The combined effect of mixing and carbon addition on nitrate removal}

The combined effect of mixing and carbon addition on nitrate removal was investigated through column experiments. During phase I of the experiments, methanol was added as a carbon source (methanol $/ \mathrm{NO}_{3}{ }^{-}-\mathrm{N}$ mass ratio of $4: 1$ ). One treatment was mixed, and the other treatment was not. As shown in Fig.5, the results verified that mixing accelerated nitrate removal. After 9 days of acclimation, 
the $\mathrm{NO}_{3}{ }^{-}-\mathrm{N}$ removal increased to a relatively high level. During the next three rounds of the experiment, the $\mathrm{NO}_{3}{ }^{-}-\mathrm{N}$ and $\mathrm{TN}$ in carbon addition plus mixing column decreased rapidly, with an average removal rate of $5.68 \mathrm{~g} \mathrm{~m}^{-2} \mathrm{~d}^{-1}$ and $5.17 \mathrm{~g} \mathrm{~m}^{-2} \mathrm{~d}^{-1}$, respectively. Comparatively, in the carbon addition without mixing column, a much lower rate of removal of $\mathrm{NO}_{3}{ }^{-}-\mathrm{N}$ and $\mathrm{TN}$ was maintained, with an average removal rate of $2.91 \mathrm{~g} \mathrm{~m}^{-2} \mathrm{~d}^{-1}$ and $2.72 \mathrm{~g} \mathrm{~m}^{-2} \mathrm{~d}^{-1}$. The positive effect of mixing on nitrate removal can be explained by the increase of the diffusive $\mathrm{NO}_{3}{ }^{-}$and carbon supply across the water-sediment interface as mentioned above.

The main objective of phase II was to determine the influence of the different carbon sources combined with mixing. Different carbon sources, including the debris of the floating plant Eichhornia crassipes and the submerged plant Hydrilla verticillata and ethanol were added to the mixing columns. As shown in fig.6, Hydrilla verticillata promotes $\mathrm{NO}_{3}{ }^{-}-\mathrm{N}$ removal compared to control column. However, in the column with Eichhornia crassipes, the lowest $\mathrm{NO}_{3}{ }^{-}-\mathrm{N}$ removal was observed. Additional studies suggested that a large amount of $\mathrm{NH}_{4}{ }^{+}$was released with the decomposition of Eichhornia crassipes. This may be the reason for the low removal of $\mathrm{NO}_{3}{ }^{-}-\mathrm{N}$. For the ethanol addition (ethanol / $\mathrm{NO}_{3}{ }^{-}-\mathrm{N}$ mass ratio of 4:1) plus mixing column, the $\mathrm{NO}_{3}{ }^{-}-\mathrm{N}$ removal was the highest. The $\mathrm{NO}_{3}{ }^{-}-\mathrm{N}$ decreased from 7.4 $\mathrm{mg} \mathrm{L}^{-1}$ to $0.6 \mathrm{mg} \mathrm{L}^{-1}$, with a removal rate of $1.6 \mathrm{~g} \mathrm{~m}^{-2} \mathrm{~d}^{-1}$ during the first 5 days. On the $10^{\text {th }}$ day, ethanol and $\mathrm{NO}_{3}^{-}-\mathrm{N}$ was added again, and a much higher removal rate was obtained. This increase in the removal rate was similar to the batch test, indicating that the denitrifying bacteria were gradually acclimated.

Thereafter, another three rounds of removal experiments were conducted with the same ethanol / $\mathrm{NO}_{3}{ }^{-}-\mathrm{N}$ mass ratio. During these treatments, the removal rate of $\mathrm{NO}_{3}{ }^{-}-\mathrm{N}$ and $\mathrm{TN}$ was as high as 15.0-16.5 $\mathrm{g} \mathrm{m}^{-2}$ $\mathrm{d}^{-1}$

The column experiments show that although the decomposable plant material had a positive effect on 
denitrification, the increase was very limited. Comparatively, molecular organic compounds have high bioavailability and are easy to metabolize. Studies had shown that adding molecular organic compounds can significantly increase the nitrate removal in wetlands. For example, Kozub and Liehr (1999) performed experiments on wetland microcosms, and they observed that adding acetate as an external carbon source led to significantly increased denitrification rates. However, the reported nitrate removal capacity was always below $5 \mathrm{~g} \mathrm{~m}^{-2} \mathrm{~d}^{-1}$. As suggested in our column experiment, ethanol and methanol addition plus mixing significantly improved the nitrate removal. After 14 days of acclimation, the nitrate removal rate increased approximately 10 fold, from $1.6 \mathrm{~g} \mathrm{~m}^{-2} \mathrm{~d}^{-1}$ to $16.5 \mathrm{~g} \mathrm{~m}^{-2} \mathrm{~d}^{-1}$. Comparatively, the ethanol addition treatment showed a higher nitrate removal capacity than the methanol treatment.

\subsection{Wetland microcosm}

To verify the feasibility of enhancing nitrate removal by carbon addition plus mixing, a small-scale experiment was conducted with a wetland microcosm. A steady state was achieved after 10 days of operation, and the removal efficiency in the two units remained almost constant for the following 25 days. The concentrations of pollutants in the influent and effluents were averaged, and the values for the pollutant load, pollutant removal, removal efficiency, and removal of pollutant load were calculated to confirm the removal performance of the different units. The results are summarized in Table 1. In general, the system performed well for $\mathrm{TN}$ and $\mathrm{NO}_{3}{ }^{-} \mathrm{N}$ removal, and the removal efficiencies of $\mathrm{TN}$ and $\mathrm{NO}_{3}{ }^{-}-\mathrm{N}$ all exceeded $90 \%$ at a hydraulic loading rate of $0.5 \mathrm{~m} / \mathrm{d}$. The floating plant pond also exhibited significant nitrogen removal capacity. Approximately $89.0 \%$ of the TN load and $91.1 \%$ of the $\mathrm{NO}_{3}{ }^{-}$load were eliminated in the floating plant pond. The removal rate of $\mathrm{NO}_{3}{ }^{-}-\mathrm{N}$ and $\mathrm{TN}$ was as high as $10.0-12.0$ $\mathrm{g} \mathrm{m}^{-2} \mathrm{~d}^{-1}$, suggesting that denitrification was successfully achieved. By comparison, the highest reduction rate of our wetland microcosm was approximately $12 \mathrm{~g} \mathrm{~m}^{-2} \mathrm{~d}^{-1}$, much higher than the majority of values 
achieved in wetlands and ponds. Therefore, as shown with the successful operation of this small-scale wetland, simple engineering measures can efficiently remove nitrate.

\subsection{Implications for practice}

In wetlands and ponds, the overlying water is usually aerobic, and the bottom water DO declines steeply when it approaches to sediment. As a result, an oxic-anoxic layer forms at the sediment-water interface. Such oxic-anoxic layer, although as shallow as $10 \mathrm{~mm}$, has a remarkable biological activity, and can favor both coupled and decoupled denitrification (Sweerts et al., 1991; Jensen, et al., 1993;

Wilson, et al., 2013). According to recent studies, steep vertical profiles of nitrate and carbon are likely to occur at sediment-water interface, and further limit the benthic denitrification (Reinhardt, et al., 2006; Wilson, et al., 2013). Our investigation provides evidence that such vertical profiles can be artificially controlled by carbon addition plus vertical mixing, and thus benefits the nitrate removal. However, the vertical profiles of parameters across sediment-water interface in response to the manipulation should be further investigated.

On the other side, sediment-water interface can be considered as a kind of natural substrate that denitrifying bacteria has already attached on it. Therefore, when additional carbon is supplied, it takes a short time to acclimate and to achieve a high nitrate removal. Such rapid response favors engineering practice. Moreover, for practical application, the proper way to mix water should be fixed out. There are two essential issues for the engineering design including: the mixing device should be able to mix a large amount of overlying water at low cost; and meanwhile it should not significantly increase the DO in bottom water. Accordingly, air lifting devices which previously used for artificial destratification in deep reservoirs may be modified to meet the requirement (Heo and Kim, 2004).

\section{Conclusions}


On the basis of the results we conclude that:

1) The sediment-water interface has a great potential for nitrate removal, and adding additional carbon plus mixing significantly increases the nitrate removal capacity. A first-order reaction model can be used to fit the removal of $\mathrm{TN}$ and $\mathrm{NO}_{3}{ }^{-}-\mathrm{N}$ at water-sediment interface.

2) Adding Hydrilla verticillata debris as a carbon source increased nitrate removal, whereas adding Eichhornia crassipe decreased it. Adding ethanol plus mixing greatly improved the removal performance, with the removal rate of $\mathrm{NO}_{3}{ }^{-} \mathrm{N}$ and $\mathrm{TN}$ reaching $15.0-16.5 \mathrm{~g} \mathrm{~m}^{-2} \mathrm{~d}^{-1}$.

3) The small-scale wetland experiment showed that the $\mathrm{NO}_{3}{ }^{-}-\mathrm{N}$ removal rate of the wetland maintained 10.0-12.0 $\mathrm{g} \mathrm{m}^{-2} \mathrm{~d}^{-1}$ with a hydraulic loading rate of $0.5 \mathrm{~m} / \mathrm{d}$. This is almost the highest removal rate ever reported for free-surface wetland or ponds, suggesting carbon addition plus mixing is a simple but effective measure to improve nitrate removal in wetlands or ponds that receive effluents from sewage plants or agricultural non-point sources.

\section{Acknowledgements}

The present work was supported by the State Oceanic Administration of China (Demonstration project of coastal wetland restoration, north coast of Hangzhou Wan bay), the National Science Foundation of China under Grant No. 51378306 and 41471393, and Science and Technology Planning Project of Zhejiang Province No.2014F50003.

\section{References}

APHA, 1995. Standard Methods for the Examination of Water and Wastewater, 19ed. American

Public Health Association, Washington, DC.

Bastviken, S.K., Eriksson, P.G., Premrov, A., Tonderski, K., 2005. Potential denitrification in wetland sediments with different plant species detritus. Ecol. Eng. 25, 183-190. 
Bruesewitz, D.A., Hamilton, D.P., Schipper, L.A., 2011. Denitrification Potential in Lake Sediment Increases Across a Gradient of Catchment Agriculture. Ecosystems 14, 341-352.

Coveney, M.F., Stites, D.L., Lowe, E.F., Battoe, L.E., Conrow, R., 2002. Nutrient removal from eutrophic lake water by wetland filtration. Ecol. Eng. 19, 141-159.

Finlay, J.C., Small, G.E., Sterner, R.W., 2013. Human influences on nitrogen removal in lakes. Science 342, 247-250.

Galloway, J.N., Townsend, A.R., Erisman, J.W., Bekunda, M., Cai, Z., Freney, J.R., Martinelli, L.A., Seitzinger, S.P., Sutton, M.A., 2008. Transformation of the nitrogen cycle: Recent trends, questions, and potential solutions. Science 320, 889-892.

He, S.B., Gao, J.W., Chen, X.C., Dai, D.L., 2013. Nitrogen removal in micro-polluted surface water by the combined process of bio-filter and ecological gravel bed. Water. Sci. Technol. 67, 2356-2362.

Heo, W.M., Kim, B., 2004. The effect of artificial destratification on phytoplankton in a reservoir. Hydrobiologia 524, 229-239.

Ingersoll, T.L., Baker, L.A., 1998. Nitrate removal in wetland microcosms. Water. Res. 32, 677-684. Jensen K., Revsbech N.P., Nielsen L. P., 1993. Microscale distribution of nitrification activity in sediment determined with a shielded microsensor for nitrate. Appl. Environ. Microb. 59, 3287-3296. Jorgensen, S.E., Nielsen, L.K., Ipsen, L.G.S., Nicolaisen, P., 1994. Lake restoration using a reed swamp to remove nutrients from non-point sources. Wetlands Ecology and Management 3(2), 87-95.

Kozub, D.D., Liehr, S.K., 1999. Assessing denitrification rate limiting factors in a constructed wetland receiving landfill leachate. Water. Sci. Technol. 40, 75-82.

Kroeger, K. D., Cole M. L., Valiela I., 2006. Groundwater-transported dissolved organic nitrogen exports from coastal watersheds. Limnol. Oceanogr. 51, 2248-2261. 
Lerman, A. 1978. Chemical exchange across sediment-water interface. Annu. Rev. Earth Planet. Sci.

6, 281-303.

Lin, Y.F., Jing, S.R., Wang, T.W., Lee, D.Y., 2002. Effects of macrophytes and external carbon sources on nitrate removal from groundwater in constructed wetlands. Environ. Pollut. 119, 413-420.

Pfenning, K.S., McMahon, P.B., 1997. Effect of nitrate, organic carbon, and temperature on potential denitrification rates in nitrate-rich riverbed sediments. J. Hydrol. 187, 283-295.

Pungrasmi, W., Playchoom, C., Powtongsook, S., 2013. Optimization and evaluation of a bottom substrate denitrification tank for nitrate removal from a recirculating aquaculture system. J. Environ. Sci. 25, 1557-1564.

Reilly, J.F., Horne, A.J., Miller, C.D., 1999. Nitrate removal from a drinking water supply with large free-surface constructed wetlands prior to groundwater recharge. Ecol. Eng. 14, 33-47.

Reinhardt, M., Müller, B., Gächter, R., Wehrli, B., 2006. Nitrogen removal in a small constructed wetland: An isotope mass balance approach. Environ. Sci. Tech. 40, 3313-3319.

Suddick, E.C., Whitney, P., Townsend, A.R., Davidson, E.A., 2013. The role of nitrogen in climate change and the impacts of nitrogen-climate interactions in the United States: Foreword to thematic issue. Biogeochemistry 114, 1-10.

Sweerts, J.P., Baer-Gilissen M.J., Cornelese A.A., Cappenberg T.E., 1991. Cappenberg Oxygen consuming processes at the profundal and littoral sediment-water interface of a small meso-eutrophic lake (Lake Vechten, The Netherlands). Limnol. Oceanogr. 36, 1124-1133.

Vidal, S., Rocha, C., Galvão, H., 2002. A comparison of organic and inorganic carbon controls over biological denitrification in aquaria. Chemosphere 48, 445-451.

Wen, Y., Chen, Y., Zheng, N., Yang, D., Zhou, Q., 2010. Effects of plant biomass on nitrate removal 
and transformation of carbon sources in subsurface-flow constructed wetlands. Bioresource Technology 101(19), 7286-7292.

Wilson, R.F., Fennel, K., Paul Mattern, J., 2013. Simulating sediment-water exchange of nutrients and oxygen: A comparative assessment of models against mesocosm observations. Cont. Shelf. Res. 63, 69-84.

Yu, H., Song, Y., Xi, B., Du, E., He, X., Tu, X., 2012. Denitrification potential and its correlation to physico-chemical and biological characteristics of saline wetland soils in semi-arid regions.

Chemosphere 89, 1339-1346.

Figures and Table

Floating plants pond Gravel bed filter

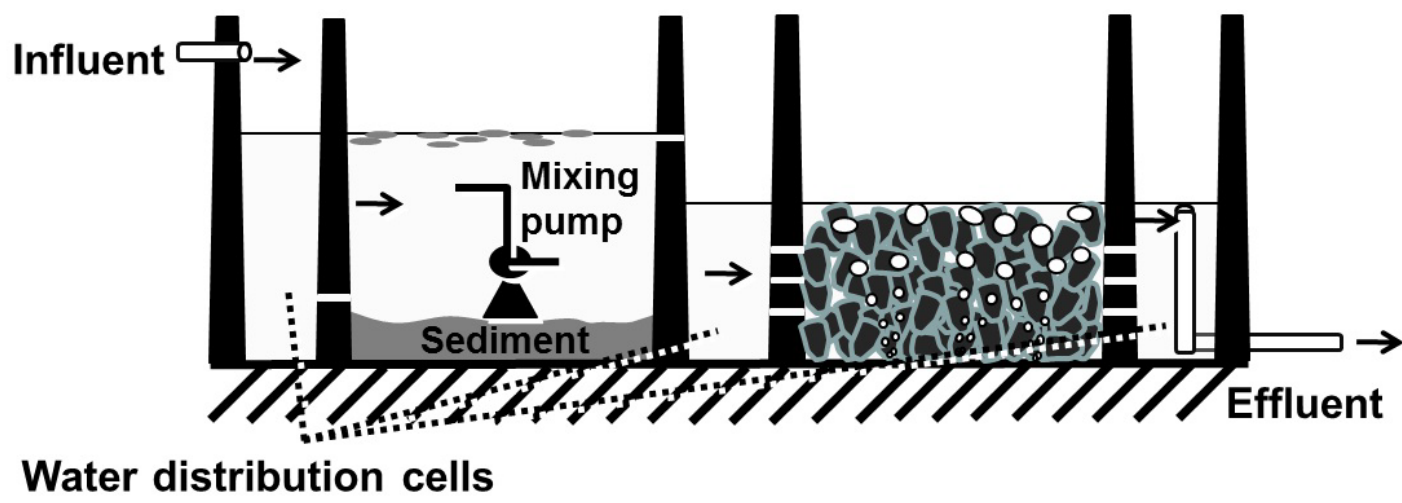

Fig. 1. Schematic diagram of the wetland microcosm experimental set-up. 

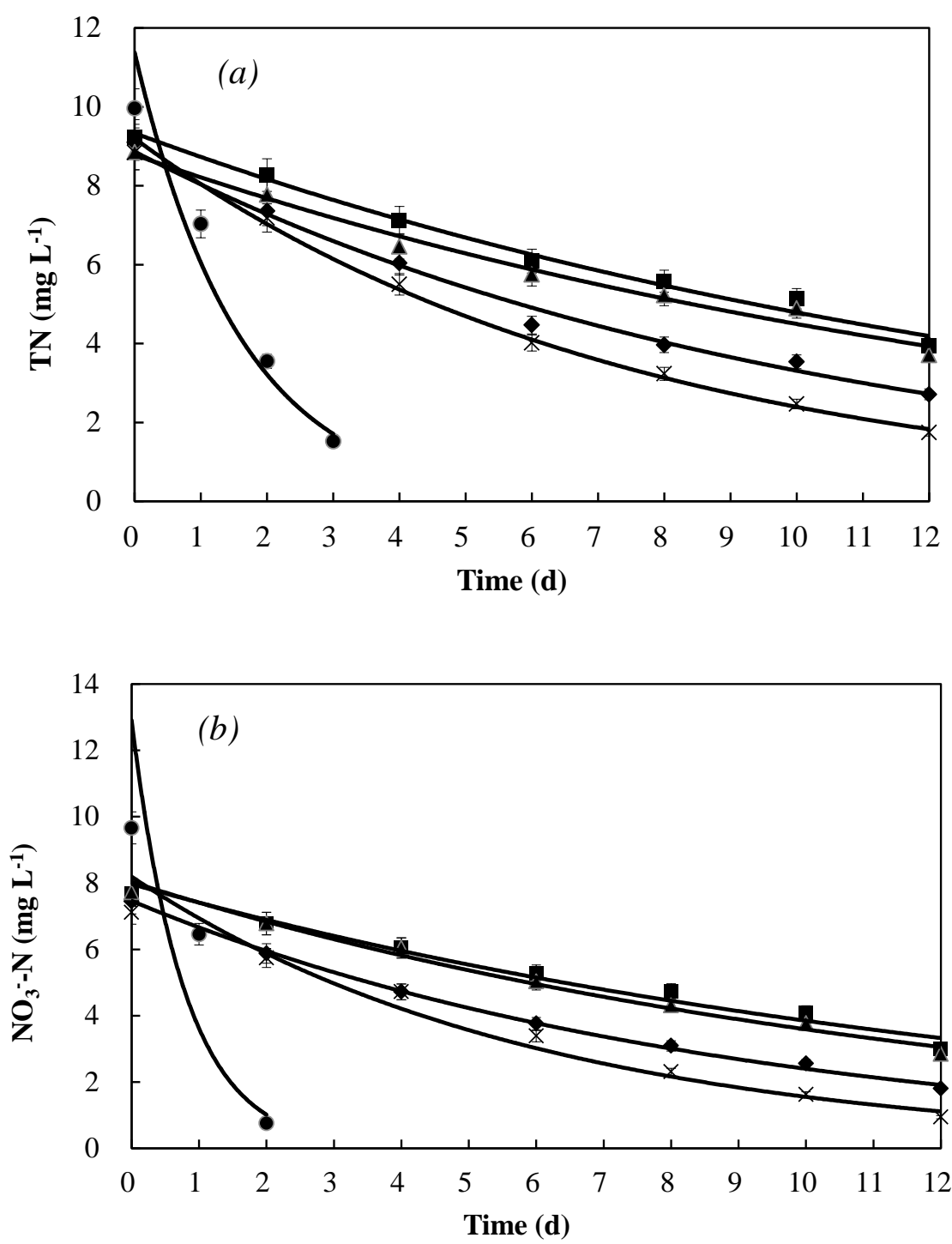

Fig. 2. The nitrate removal under different sediment-water interface conditions and exponential curve fitting (a) Exponential curve fit for TN concentration as a function of time, - •- for carbon addition, $C=11.38 \mathrm{e}^{-0.63 \mathrm{~T}}, \mathrm{R}^{2}=0.97 ;-\boldsymbol{-}$ - for mixing, $\mathrm{C}=9.43 \mathrm{e}^{-0.15 \mathrm{~T}}, \mathrm{R}^{2}=0.99 ;-\boldsymbol{\Delta}$ - for zeolite covering, $\mathrm{C}=9.47 \mathrm{e}^{-0.071 \mathrm{~T}}$, $\mathrm{R}^{2}=0.99 ;-\mathbf{m}$ - for gravel covering, $\mathrm{C}=8.72 \mathrm{e}^{-0.066 \mathrm{~T}}, \mathrm{R}^{2}=0.99 ;-\boldsymbol{-}$ for control, $\mathrm{C}=8.97 \mathrm{e}^{-0.10 \mathrm{~T}}, \mathrm{R}^{2}=0.99$.

(b) Exponential curve fit for $\mathrm{NO}_{3}{ }^{-} \mathrm{N}$ concentration as a function of time, - $\bullet$ - for carbon addition, $C=12.91 \mathrm{e}^{-1.27 \mathrm{~T}}, \mathrm{R}^{2}=0.87 ;-\times$ - for mixing, $\mathrm{C}=8.19 \mathrm{e}^{-0.17 \mathrm{~T}}, \mathrm{R}^{2}=0.97 ;-\boldsymbol{\Delta}$ - for zeolite covering, $\mathrm{C}=8.03 \mathrm{e}^{-0.081 \mathrm{~T}}$, $\mathrm{R}^{2}=0.98$; - $\mathbf{-}$ - for gravel covering, $\mathrm{C}=7.97 \mathrm{e}^{-0.073 \mathrm{~T}}, \mathrm{R}^{2}=0.96$; $-\bullet$ - for control, $\mathrm{C}=7.46 \mathrm{e}^{-0.11 \mathrm{~T}}, \mathrm{R}^{2}=0.99$. 

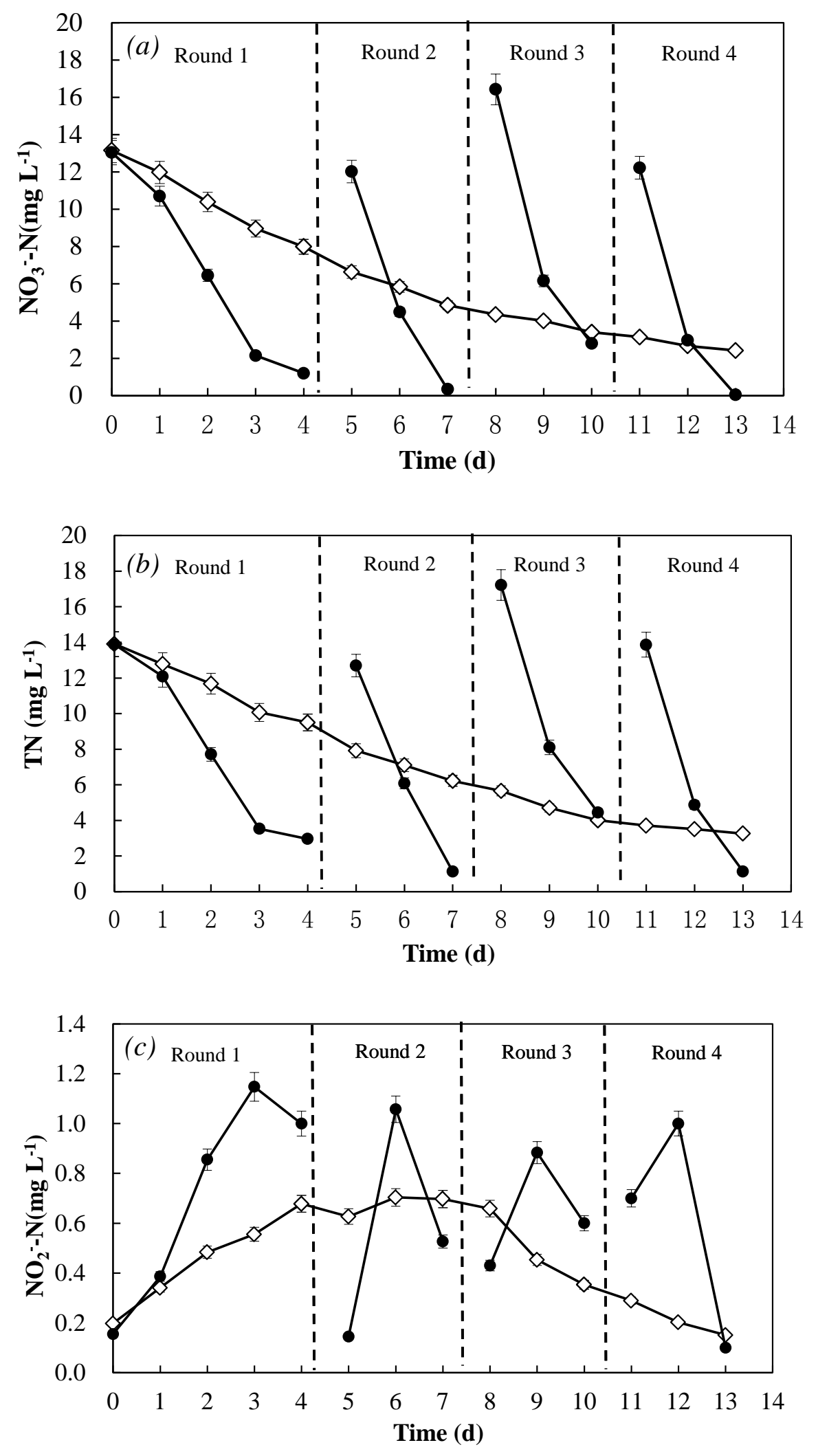


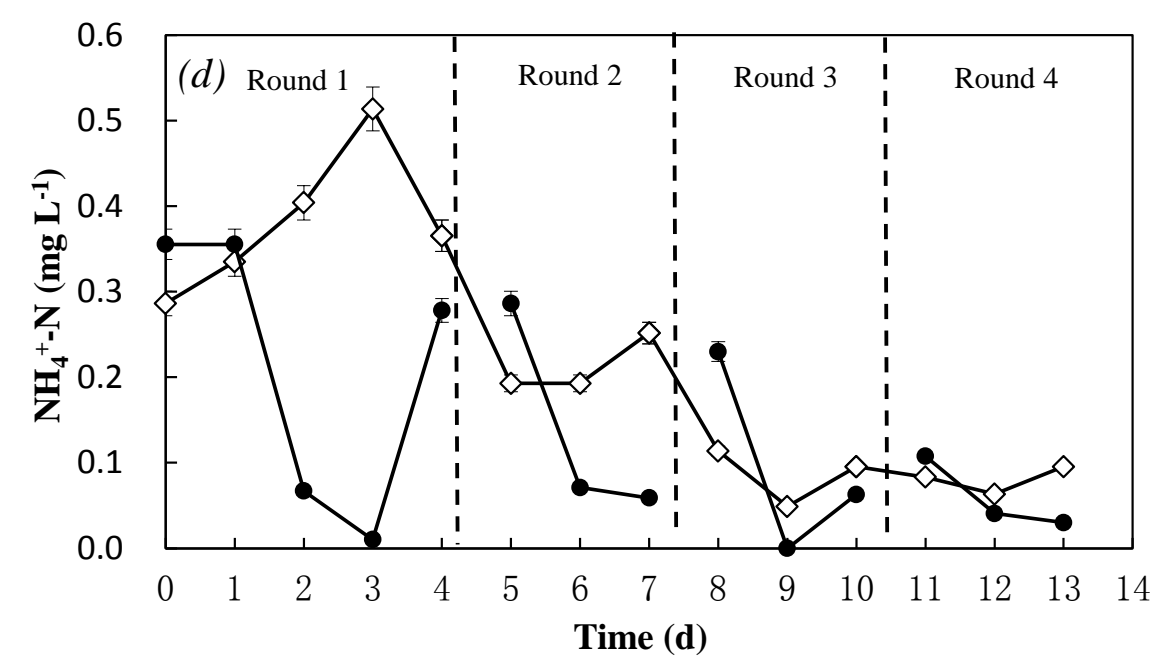

Fig. 3. Enhancement of nitrate removal by carbon addition. (a) $\mathrm{NO}_{3}^{-}-\mathrm{N}$; (b) TN; (c) $\mathrm{NO}_{2}^{-}-\mathrm{N}$; (d) $\mathrm{NH}_{4}{ }^{+}-\mathrm{N}$,

-•- Carbon addition, - $\diamond$-Control

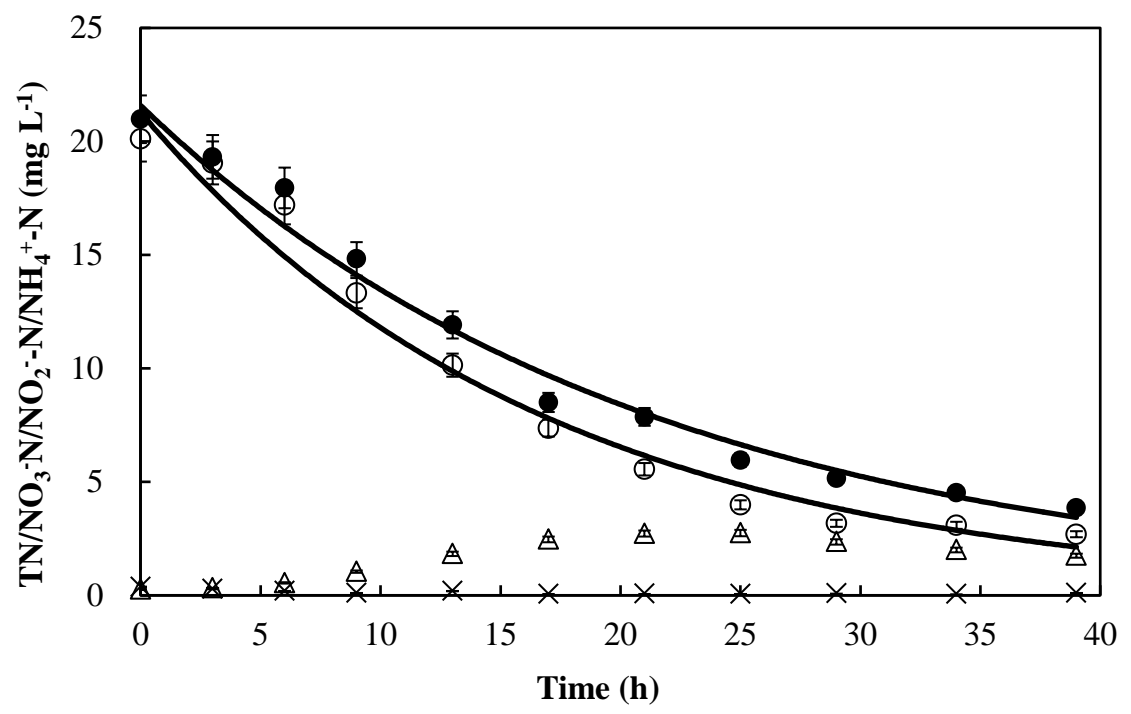

Fig. 4. Dynamic of N removal after acclimation -•- Exponential curve fit for TN as a function of time, $y=21.57 e^{-1.13 x}, R^{2}=0.98 ;-0$ - Exponential curve fit for $\mathrm{NO}_{3}{ }^{-}-\mathrm{N}$ as a function of time, $\mathrm{y}=21.27 \mathrm{e}^{-1.42 \mathrm{x}}$, $\mathrm{R}^{2}=0.97 ;-\Delta-\mathrm{NO}_{2}{ }^{-}-\mathrm{N} ;-\mathrm{X}-\mathrm{NH}_{4}{ }^{+}-\mathrm{N}$. 


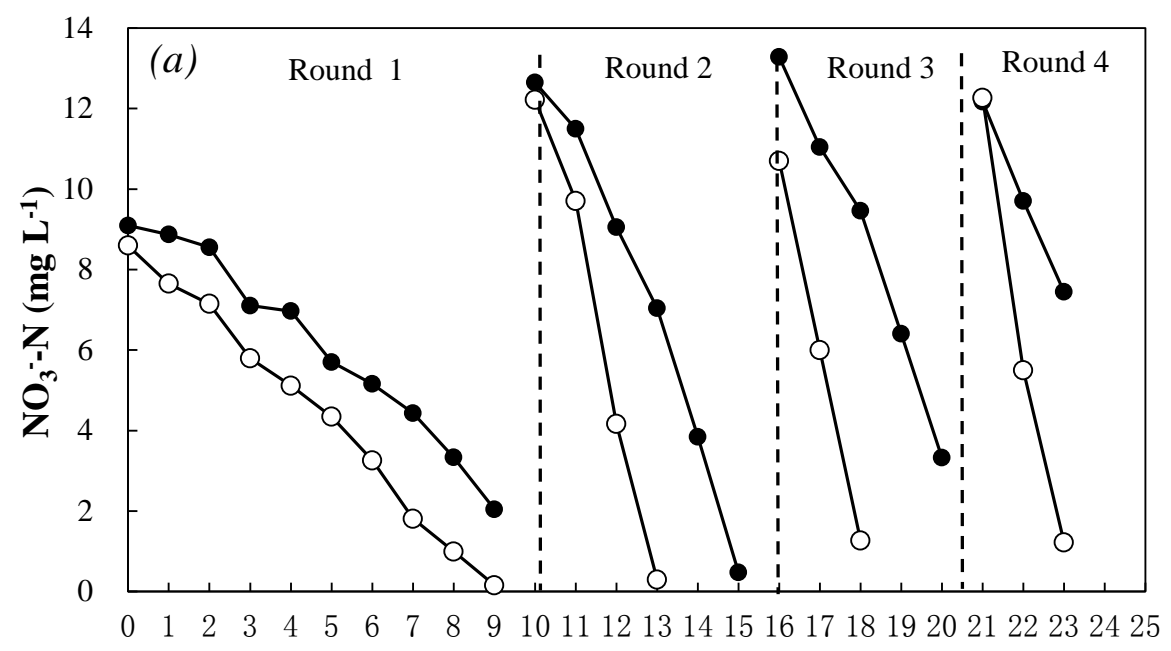

Time (d)

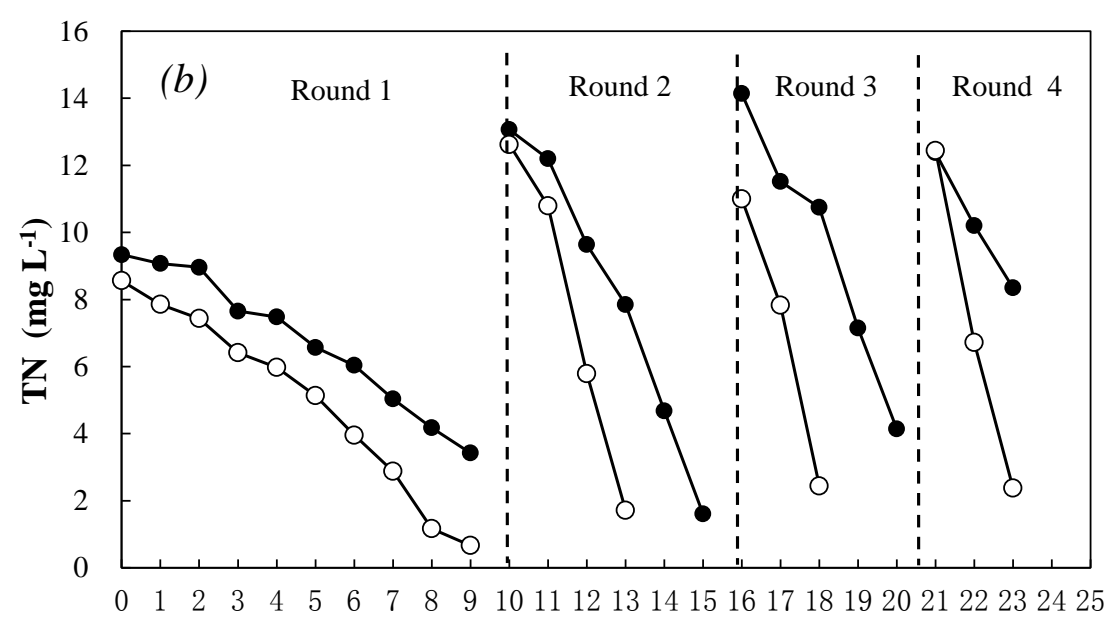

Time (d)

Fig. 5. Influence of mixing on $\mathrm{NO}_{3}^{-}-\mathrm{N}(a)$ and TN (b) removal. - •- Carbon addition; - - - Carbon addition plus mixing. 

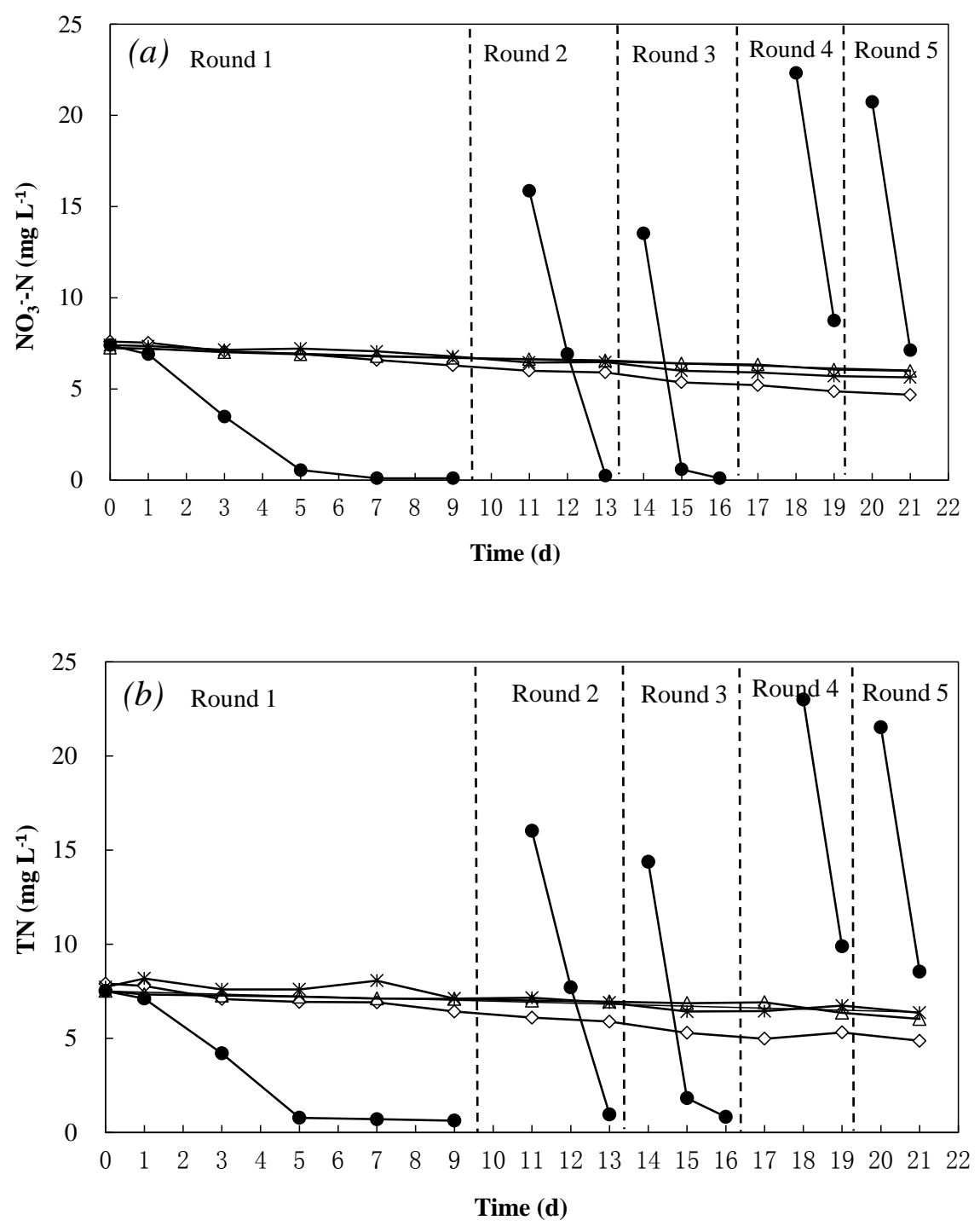

Fig. 6. Influence of carbon sources on $\mathrm{NO}_{3}{ }^{-} \mathrm{-N}(a)$ and TN (b) removal. -•-:Ethanol; - $\triangle$-:Eichhornia crassipes; - $\diamond-:$ Hydrilla verticillata; and -*-: Control

Table1 Removal performance of the entire purification system and each treatment unit

\begin{tabular}{lllll}
\hline Sampling locations (n=25) & $\mathrm{TN}$ & $\mathrm{NO}_{3}{ }^{-} \mathrm{N}$ & $\mathrm{NO}_{2}{ }^{-} \mathrm{N}$ & $\mathrm{NH}_{4}{ }^{+}-\mathrm{N}$ \\
\hline
\end{tabular}

Entire treatment system

$\begin{array}{lllll}\text { Influent Concentration } & 25.5 \pm 1.3 & 23.6 \pm 1.1 & 0.2 \pm 0.1 & 0.1 \pm 0.1 \\ \text { Effluent concentration } & 2.2 \pm 0.5 & 1.3 \pm 0.7 & 0.6 \pm 0.3 & 0.1 \pm 0.2\end{array}$




\begin{tabular}{lccc|} 
Pollutant Load $\left(\mathrm{g} \mathrm{m}^{-2} \mathrm{~d}^{-1}\right)$ & 12.75 & 11.80 & $/$ \\
Pollutant removal $\left(\mathrm{g} \mathrm{m}^{-2} \mathrm{~d}^{-1}\right)$ & 11.65 & 11.15 & $/$ \\
Removal efficiency (\%) & 91.4 & 94.5 & $/$
\end{tabular}

\section{Floating plant pond}

\begin{tabular}{ccccc} 
Effluent concentration & $2.8 \pm 0.2$ & $2.1 \pm 0.1$ & $0.5 \pm 0.1$ & $0.1 \pm 0.1$ \\
Removal efficiency (\%) & 89.0 & 91.1 & $/$ & $/$ \\
Pollutant removal $\left(\mathrm{g} \mathrm{m}^{-2} \mathrm{~d}^{-1}\right)$ & 11.35 & 10.75 & $/$ & $/$ \\
Gravel bed filter & & & & \\
Effluent concentration & $2.2 \pm 0.5$ & $1.3 \pm 0.7$ & $0.6 \pm 0.3$ & $0.1 \pm 0.2$ \\
Removal efficiency (\%) & 21.4 & 38.1 & $/$ & $/$ \\
Pollutant removal $\left(\mathrm{g} \mathrm{m}^{-2} \mathrm{~d}^{-1}\right)$ & 0.90 & 1.20 & $/$ & $/$ \\
\hline
\end{tabular}

